\title{
Evaluation of a novel quantitative canine species-specific point-of-care assay for C-reactive protein
}

\author{
Sarah Hindenberg ${ }^{1 *}$, Melanie Keßler ${ }^{1}$, Sabine Zielinsky ${ }^{1}$, Judith Langenstein ${ }^{2}$, Andreas Moritz $^{1}$ and Natali Bauer ${ }^{1}$
}

\begin{abstract}
Background: Species-specific point-of-care tests (POCT) permit a rapid analysis of canine C-reactive protein (CRP), enabling veterinarians to include CRP in clinical decisions. Aim of the study was to evaluate a novel POCT for canine CRP (Point Strip ${ }^{\text {TM }}$ Canine CRP Assay) run on a small in-house-analyzer (Point Reader ${ }^{\mathrm{TM}} \mathrm{V}$ ) using lithium heparin plasma and to compare assay performance to an already established canine CRP assay (Gentian Canine CRP Immunoassay) run on two different bench top analyzers serving as reference methods (ABX Pentra 400, AU 5800).

Linearity was assessed by stepwise dilution of plasma samples with high CRP concentrations. Limit of quantification (LoQ) was determined by repeated measurements of samples with low CRP concentrations. Coefficient of variation (CV) at low (10-50 mg/l), moderate (50-100 mg/l), and high (100-200 mg/l) CRP concentrations was investigated as well as possible interferences. Method comparison study was performed using 45 samples of healthy and diseased dogs. Quality criteria were fulfilled if the total observed error ( $\left(\mathrm{TE}_{\mathrm{obs}}=2 \mathrm{CV} \%+\right.$ bias\%) was below the minimal total allowable error of $44.4 \%$ ( $\mathrm{TE}$ min). Additionally, a reference range ( $n=60$ healthy dogs) was established.

Results: Linearity was present at CRP concentrations of 10-132 mg/l (^ $361 \mathrm{mg} / \mathrm{l} \mathrm{CRP}$ with reference method) with a LoQ set at $10 \mathrm{mg} / \mathrm{l}$. At moderate to high CRP concentrations, intra- and inter-assay CVs were $\leq 8 \%$ and $\leq 11 \%$ respectively, while CVs $\leq 22 \%$ and $\leq 28 \%$ were present at low concentrations. No interferences were observed at concentrations of $4 \mathrm{~g} / \mathrm{l}$ hemoglobin, $800 \mathrm{mg} / \mathrm{l}$ bilirubin and $8 \mathrm{~g} / \mathrm{l}$ triglycerides. Method comparison study demonstrated an excellent correlation with both reference methods ( $r=0.98$ for ABX Pentra 400; 0.99 for AU 5800), though revealing a proportional bias of 19.7\% (ABX Pentra 400 ) and 10.7\% (AU 5800) respectively. TE obs $_{\text {was }} 26.7-31.9 \%$ and $16.7-21.9 \%$ and thus $<\mathrm{TE}_{\mathrm{min}}$. Healthy dogs presented with CRP values $\leq 11.9 \mathrm{mg} / \mathrm{l}$.
\end{abstract}

Conclusions: The POCT precisely detects canine CRP at clinically relevant moderate and high CRP concentrations. The assay correlates well with both reference methods. Due to the bias, however, follow-up examinations should be performed with the same assay and analyzer.

Keywords: Acute phase protein, C-reactive protein, Canine, Method validation, Point-of-care assay, Point-of-care analyzer, Total allowable error, Bias, Heparin plasma, Interference

\section{Background}

C-reactive protein $(\mathrm{CRP})$ is an important major acute phase protein (APP) in the dog. APPs are an integral part of innate immune response and change their serum concentration in adaption to a systemic inflammation [1-4]. Contrary to classic markers of inflammation as

\footnotetext{
* Correspondence: sarah.hindenberg@vetmed.uni-giessen.de

'Department of Veterinary Clinical Sciences, Clinical Pathology and Clinical Pathophysiology, Justus-Liebig-University Giessen, Frankfurter Str. 126, 35392 Giessen, Germany

Full list of author information is available at the end of the article
}

the white blood cell count, APPs react more rapidly and with a shorter half-life period $[1,5]$. According to their kinetics, APPs are classified as slowly and mildly reacting minor and moderate APP or as rapidly reacting major APP, which increase 100- to 1000-fold within 24-48 $\mathrm{h}$ and decrease rapidly after disappearance of the inflammatory stimulus [3]. These sensitive markers of inflammation have been shown to increase in response to infectious diseases [6-9], immune mediated diseases [10-12], neoplasia [10,13, 14], and surgery [15]. 
However, in the past, the measurement of canine CRP was hampered by the lack of a species-specific test available for veterinary practices and clinics.

Different assays for canine CRP were developed or adopted from human medicine and there was a shift from heterologous to homologous immunoassays which provide more reliable results [16-19]. Recently, a commercially available canine CRP assay was introduced on the market that is designed to be run on automated large bench top analyzers. First evaluations demonstrated its capability to detect canine CRP with a high precision and accuracy [20]. However, patients with severe inflammatory processes are often presented as emergency cases, so that a rapid measurement of CRP is desirable.

In human medicine, near-patient assays are available in order to fulfill this aim [21,22].

Few canine species-specific CRP in-house tests have been evaluated in the past. The first point-of-care tests (POCT) were only semiquantitative, providing results of limited benefit and leading sometimes to falsely positive results [23-26]. Later, quantitative assays became available $[27,28]$. Method comparison studies have often been performed with a manual ELISA serving as reference method, which, however, is impaired by a lack of precision.

Recently, a novel quantitative homologous bedside canine CRP assay (Point Strip ${ }^{\text {Tw }}$ Canine CRP Kit, USHIO Europe B.V., BC Oude Meer, The Netherlands) run on the in-house analyzer Point Reader ${ }^{\text {nt }}$ V, USHIO Europe B.V., BC Oude Meer, The Netherlands became commercially available. The Point Strip ${ }^{\text {Tu }}$ Canine CRP assay for the Point Reader $^{\text {TM }} \mathrm{V}$ is a test strip based colloidal gold immunochromatographic assay with species-specific rabbit anti-dog-CRP antibodies, which form complexes with canine CRP. These complexes migrate by capillary action through the membrane and are bound to the test line. Remaining non-bound antibodies are bound to the control line. The same test principle was used in a semiquantitative assay before [25].

Thus, it was the aim of our study to evaluate the ease of use and the test performance including linearity and lower limit of quantification (LoQ), precision and total observed error $\left(\mathrm{TE}_{\mathrm{obs}}\right)$ as well as interferences with bilirubin, hemoglobin and lipid of the canine speciesspecific in-house CRP assay run on the Point Reader ${ }^{\text {rm }} \mathrm{V}$. In a method comparison study, the assay was compared with a canine CRP test which has been validated before $[20,29]$ run on two automated analyzers serving as reference methods. Furthermore, the reference range was evaluated. The hypothesis was that the investigated point-of-care analyzer is easy-to-use and that the results obtained with the POCT correlate well with the reference bench top analyzers.

\section{Methods}

The prospective study was performed between September 2016 and July 2017.

\section{Measurement of CRP}

Analyses were performed on surplus lithium heparin plasma submitted for CRP analysis to the Department of Veterinary Clinical Sciences, Clinical Pathology and Clinical Pathophysiology, Justus-Liebig-University Giessen, Germany. Samples were analyzed immediately $(<1 \mathrm{~h}$ after blood collection) with the Gentian Canine CRP Immunoassay (Gentian AS, Moss, Norway), which served as the reference assay, on the ABX Pentra 400 clinical chemistry analyzer (ABX Horiba, Montpellier, France) as described before [29]. The initially performed CRP analysis as part of routine diagnostics was used to assign the sample to one of the three concentration ranges: CRP 10-50 mg/l (low); 50-100 mg/l (medium), and $100-200 \mathrm{mg} / \mathrm{l}$ (high). The application of reagents and samples and the measurements on the in-house analyzer as well as on the large bench top analyzers were done by a single trained person for each analyzer according to the manufacturer's instructions. In the method comparison study, the Point Strip ${ }^{\text {ma }}$ Canine CRP POCT run on the Point Reader ${ }^{\text {Tn }} \mathrm{V}$ (test and analyzer combination is subsequently just named "Point Reader ${ }^{\mathrm{ru}}$ $\mathrm{V}$ " or "POCT") was compared to the reference assay run on two bench top analyzers (ABX Pentra 400, ABX Horiba, Montpellier, France and AU 5800, Beckman Coulter, Krefeld, Germany).

\section{Method validation}

Linearity and recovery Linearity was evaluated by manual stepwise dilution of two canine lithium heparin plasma samples with markedly increased CRP concentration of $\sim 245$ and $360 \mathrm{mg} / \mathrm{l}$ determined on the ABX Pentra 400 analyzer which was used as a reference method. Serial dilution resulted in specimens with 1.0, $0.8,0.6,0.4,0.2,0.1,0.05$, and 0.025 of the original CRP concentration. All diluted aliquots were analyzed in triplicates in a single run. For all dilution steps \% recovery rate was evaluated by comparison of expected and measured results. Furthermore, the dilution series was used for calculation of the recovery rate. The experiment was conducted twice to verify the measurements.

Precision and lower limit of quantification Precision was assessed at three CRP concentration levels, i.e. low, moderate and high CRP concentrations. Intra- and interassay coefficients of variation (CVs) for the POCT were calculated from replicate measurements performed with samples of eight dogs each, whereby four samples of the lowest concentration range and two samples each of the moderate and high CRP concentration range were 
included. For assessment of intra-assay $\mathrm{CV}$, ten replicate measurements were performed ( $n=8$ dogs). Inter-assay $\mathrm{CV}$ was calculated from single measurements performed on seven consecutive days $(n=8 \mathrm{dogs})$.

For assessment of LoQ, three lithium heparin plasma samples with CRP concentrations close to zero $(20 \mathrm{mg} / \mathrm{l}$, $10 \mathrm{mg} / \mathrm{l}, 0.8 \mathrm{mg} / \mathrm{l})$ were assessed 20 times in a single run without recalibration as previously recommended [30].

Interferences In order to investigate possible interferences, aliquots of a canine lithium heparin plasma sample with a medium concentration of $\sim 50 \mathrm{mg} / \mathrm{l} \mathrm{CRP} \mathrm{as}$ assessed on the ABX Pentra 400 were spiked with $800 \mathrm{mg} / \mathrm{l}$ bilirubin (Bilirubin - $\geq 98 \%$, powder, SigmaAldrich Co. LLC., St. Louis, Missouri, USA), 4 g/l hemoglobin (hemoglobin from bovine blood, lyophilized powder, Sigma-Aldrich Co. LLC., St. Louis, Missouri, USA) or $8 \mathrm{~g} / \mathrm{l} 20 \%$ soy bean emulsion (Intralipid 20\%, Fresenius Kabi Canada, Ontario, Canada). For assessment of the effect of hyperbilirubinemia, $20 \mathrm{mg}$ bilirubin was dissolved in $1 \mathrm{ml}$ of $0.1 \mathrm{M} \mathrm{NaOH}$ obtaining a stock solution of $20 \mathrm{~g} / \mathrm{l}$. Subsequently, $5 \mu \mathrm{l}$ of the product was added to $120 \mu \mathrm{l}$ of a non-spiked lithium heparin plasma sample to achieve a bilirubin level of $800 \mathrm{mg} / \mathrm{l}$.

A stock solution containing $100 \mathrm{~g} / \mathrm{l}$ hemoglobin was prepared by diluting $30 \mathrm{mg}$ lyophilized bovine hemoglobin in $0.3 \mathrm{ml} 0.09 \% \mathrm{NaCl}$. Then, $5 \mu \mathrm{l}$ of the solution was added to $120 \mu \mathrm{l}$ non-spiked lithium heparin plasma sample resulting in a hemoglobin concentration of $4 \mathrm{~g} / \mathrm{l}$.

To evaluate the possible impact of lipemia on results, $5 \mu \mathrm{l}$ of Intralipid was added to $120 \mu \mathrm{l}$ of non-spiked lithium heparin plasma sample so that a concentration of soya bean oil of $8 \mathrm{~g} / \mathrm{l}$ was obtained. Analysis was performed in triplicates in random order. The spiked samples were investigated in comparison to lithium heparin plasma aliquots spiked with equal volumes of either $100 \mathrm{mM} \mathrm{NaOH}$ (in case of bilirubin), $0.09 \% \mathrm{NaCl}$ (hemoglobin) or pure double-distilled water (in case of Intralipid).

\section{Method comparison}

In the method comparison study, the POCT was compared to a canine CRP assay run on two bench top analyzers (ABX Pentra 400; AU 5800). First, routine biochemical analysis including measurement of CRP was performed with the ABX Pentra 400 clinical chemistry analyzer of samples submitted to the Department of Veterinary Clinical Sciences, Clinical Pathology and Clinical Pathophysiology, Justus-Liebig-University Giessen, Germany. Specimens were included in the study if it was expected that sufficient residual sample volume was available to be re-analyzed with the POCT and the two bench top analyzers ABX Pentra 400 and AU 5800, respectively. The remainder lithium heparin plasma was then divided in three aliquots and stored at
$-80{ }^{\circ} \mathrm{C}$ until analysis with the POCT and on the two bench top analyzers. Sampling was performed until 15 specimens for each CRP concentration range (low, moderate, high) were collected.

After finishing the period of sample acquisition and collecting a total number of 45 lithium heparin plasma specimens [31], two aliquots each were thawed at room temperature and re-analyzed in the Department of Veterinary Clinical Sciences, Clinical Pathology and Clinical Pathophysiology with the POCT and ABX Pentra 400 analyzer. The corresponding third aliquot of each sample was sent frozen to the commercial veterinary laboratory SYNLAB Vet GmbH, Augsburg, Germany to be analyzed on the AU 5800 analyzer. On both bench top analyzers, the same commercially available immunoturbidimetric canine specific CRP test was performed.

For all three analyzers, measurements were performed in duplicates to allow a direct comparison between the analyzers by calculation of the total observed error $\left(\mathrm{TE}_{\mathrm{obs}}\right)$ from intra-assay CV and \%bias [31].

\section{Establishment of reference intervals}

For the reference interval study, lithium heparin plasma samples of 60 healthy adult dogs (>1 year) were included. The dogs were presented at the Clinic for Small Animals, Faculty of Veterinary Medicine, JustusLiebig-University, Giessen, Germany, as blood donors or for routine radiologic examination to screen for hereditary hip or elbow dysplasia. The dogs were classified as healthy and included in the study based on an unremarkable anamnesis and clinical examination.

\section{Statistical analysis}

Statistical software programs (MedCalc, software version 16.2.1; Ostend, Belgium and GraphPad Prism 6 Software, GraphPad Software, Inc., La Jolla, USA) were used for statistical assessment of the obtained data.

\section{Method validation}

Results for CV\%, bias\% and $\mathrm{TE}_{\text {obs }}$ were compared to quality specifications derived from biologic variation published previously in the Total allowable error (TE) guidelines of the American Society of Veterinary Clinical Pathology (ASVCP, Table 1) [32]. For the purpose of the current

Table 1 Quality specifications

\begin{tabular}{|c|c|c|c|}
\hline Quality parameters & CV (\%) & Bias (\%) & TE (\%) \\
\hline - minimally acceptable & 18.2 & 14.3 & 44.4 \\
\hline - desired & 12.2 & 9.5 & 29.6 \\
\hline - optimal & 6.1 & 4.8 & 14.8 \\
\hline
\end{tabular}

Quality specifications are derived from biological variation as published in the addendum of the Total allowable error guidelines of the American Society of Veterinary Clinical Pathology [32]

Abbreviations: CV coefficient of variation, TE total allowable error 
study, numbers are rounded to one decimal place. Routine descriptive statistics were applied to calculate arithmetic means, standard deviations (SD), and CV. Normality was assessed using the Shapiro-Wilk Test.

Linearity and recovery Linearity under dilution was investigated by visual inspection of the correlation of observed CRP values plotted against a calculated (expected) CRP concentration. The difference between actual and theoretical CRP concentration was used to assess recovery after dilution:

$$
\text { Recovery } \%=\frac{\text { measured concentration }}{\text { expected concentration }} * 100
$$

The quality goal for recovery after dilution was set at the range of $80-120 \%$ as recommended previously for validation of immunoassays [33, 34]. Linear and Deming regression analysis were performed to assess the correlation between expected and measured results.

Precision and lower limit of quantification Quality requirements were fulfilled if the observed $\mathrm{CV}$ was $<$ than the desired $\mathrm{CV}\left(\mathrm{CV}_{\text {des }}\right)$ for CRP $\left(\mathrm{CV}_{\text {des }}, 12.2 \%\right)$ or at least $<$ than the minimally acceptable $\mathrm{CV}\left(\mathrm{CV}_{\min }, 18.2 \%\right)$ as reported previously [32].

Imprecision was computed based on mean and standard deviation $(\mathrm{SD})$ :

$$
\mathrm{CV} \%=\frac{\mathrm{SD}}{\text { Mean }} * 100
$$

Interferences The impact of possible interferences was evaluated by comparing control samples "spiked" with equal volumes of $\mathrm{NaOH}$ (instead of bilirubin), 0.09\% $\mathrm{NaCl}$ (instead of hemoglobin) or pure double-distilled water (instead of Intralipid) as well as samples spiked with the interfering substances (bilirubin, hemoglobin, Intralipid) which were analyzed in triplicates.

The observed interference effect $\left(\mathrm{d}_{\mathrm{obs}}\right)$ was determined as the \%bias between the mean of the test and the control samples:

$$
d_{\text {obs }} \%=\frac{\text { mean }_{\text {test }}-\text { mean }_{\text {control }}}{\text { mean }_{\text {control }}} * 100
$$

Bias between control and test sample (i.e., $\mathrm{d}_{\mathrm{obs}} \%$ ) was considered acceptable according to the current literature if it was below the allowable TE, i.e. $29.6 \%\left(\mathrm{TE}_{\mathrm{des}}\right)$ or even below $14.8 \%\left(\mathrm{TE}_{\mathrm{opt}}\right)$ for canine CRP [32, 35].

\section{Method comparison}

Statistical analysis included the calculation of CVs from duplicate measurements for all three analyzers and concentration ranges. CV quality criteria were fulfilled if $\mathrm{CV}<\mathrm{CV}_{\text {des }}(12.2 \%)$ or at least $\mathrm{CV}<\mathrm{CV}_{\text {min }}(18.2 \%)$ as shown in Table 1 [32]. The means of the duplicate measurements were used for all further statistical tests.

For method comparison, a Bland Altman analysis was performed and both, \%bias and absolute bias were calculated. Moreover, Passing Bablok analysis and calculation of Spearman's rank correlation coefficient were performed. Correlations were considered "excellent" for Spearman's rho $\left(r_{s}\right)=0.93-0.99$, "good" for $r_{s}=0.80-0.92$, "fair" for $r_{s}=0.59-0.79$, and "poor" for $r_{s}<0.59$, respectively [36].

As demonstrated in Table 1, quality criteria for bias were fulfilled if the mean observed \%Bias ${ }_{\text {obs }}<\%$ Bias $_{\text {des }}$ (desired bias) or at least $<\%$ Bias $_{\text {min }}$ (minimally acceptable bias) [32].

A Shapiro Wilk test was used to verify the assumption of normality. As non-normal distribution was present, a Kruskal-Wallis test was performed to assess a potential difference between median CRP measurements obtained for each analyzer.

To more objectively judge results, $\mathrm{TE}_{\mathrm{obs}}$ was calculated and compared with quality specifications published previously for the measurements of CRP, i.e. the desirable total allowable error $\left(\mathrm{TE}_{\mathrm{des}}\right)$ and the minimally acceptable total error $\left(\mathrm{TE}_{\min }\right)$ [32].

$\mathrm{TE}_{\mathrm{obs}}$ was calculated as published previously [27]: $\mathrm{TE}_{\mathrm{obs}}=2 * \mathrm{CV} \%+$ bias $\%$.

Quality requirements are fulfilled if $\mathrm{TE}_{\mathrm{obs}}<\mathrm{TE}_{\mathrm{des}}$ $(29.6 \%)$ or $\mathrm{TE}_{\min }(44.4 \%)$ (Table 1) [32].

\section{Establishment of reference intervals}

As healthy dogs showed CRP values frequently (54/60 dogs) below the reported CRP concentration of the point-of-care analyzer $(<5 \mathrm{mg} / \mathrm{l})$, a calculation of a definite reference interval was not possible.

\section{Results \\ Method validation \\ Ease of use}

The investigated point-of-care analyzer demonstrated to be a user-friendly in-house analyzer which could be easily used after a short training period.

Dilution buffer and test stripes have to be brought up from fridge to room temperature. Meanwhile, the analyzer is booting up and the clinician can use the time to centrifuge the blood sample to gain plasma (or serum). Then, $10 \mu \mathrm{l}$ of the sample is pipetted in the dilution bottle filled with an adequate amount of dilution buffer and mixed 10 times. Afterwards, $100 \mu \mathrm{l}$ of the dilution are applied on the test strip which is inserted in the analyzer. Measurement starts automatically and a 
result is provided after $5-10 \mathrm{~min}$ of kinetic measurement. Only if a new box of test stripes is opened, a calibration stripe for this batch of test stripes has to be inserted before measurement of a sample. All equipment (dilution bottle, test stripe) is for single use. One measurement including all preparations and waiting time for the reagents to acclimatize takes about 20-25 min. Expiration period of the test kit with 30 strips is 6 months at fridge temperature.

\section{Linearity and recovery}

The results of the two linearity experiments are shown in Fig. 1 a) and b) as well as in Table 2 a) and b).

As displayed in Fig. 1 a) and b), there was an excellent correlation between expected and measured results. For the POCT, linearity was given up to the highest CRP concentrations assessed of a mean of 123 and $130 \mathrm{mg} / \mathrm{l}$.

Comparison between expected and measured results revealed a marked proportional Bias $_{\mathrm{obs}}$ ranging between 6.8 and $63.4 \%$ (Table 2). The Bias ${ }_{\text {obs }}$ and subsequently the $\mathrm{TE}_{\mathrm{obs}}$ were exceeding quality requirements for samples with a dilution factor $\geq 0.025$ and 0.1 respectively.

\section{Precision and lower limit of quantification}

Inter- and intra- assay CVs calculated from replicate measurements are shown in Table 3. As seen in the table, intra- assay $\mathrm{CV}$ was $\leq 8 \%$ in most cases and interassay $C V \leq 11 \%$, respectively and thus $<\mathrm{CV}_{\text {des }}$ of $12.2 \%$. The only exception were samples with a relatively low CRP concentration $<25 \mathrm{mg} / \mathrm{L}$, where higher intra- and inter-assay CVs of $13.2-21.8 \%$ and $27.2 \%$ were obtained.

In the LoQ study (Table 4), the lowest sample with a CRP concentration of $0.8 \mathrm{mg} / \mathrm{l}$ was correctly reported as $<5 \mathrm{mg} / \mathrm{l}$, therefore the calculation of a CV was not possible. The CVs of 20 replicate measurements of samples with CRP concentrations of $10 \mathrm{mg} / \mathrm{l}$ and $20 \mathrm{mg} / \mathrm{l} \mathrm{re-}$ spectively fulfilled the quality goal of $\mathrm{CV}_{\text {obs }}<\mathrm{CV}_{\text {des }}$ of $12.2 \%(6.2 \%, 11 \%)$. The LoQ was set at $10 \mathrm{mg} / \mathrm{l}$ as this was the lowest CRP concentration evaluated that achieved the quality criteria.

\section{Interferences}

No interference was detectable up to a concentration of $800 \mathrm{mg} / \mathrm{l}$ bilirubin, $4 \mathrm{~g} / \mathrm{l}$ hemoglobin and $8 \mathrm{~g} / \mathrm{l}$ soy bean oil (Table 5).

Mean \% Bias $_{\text {obs }}$ between control and spiked test samples was $<\mathrm{TE}_{\mathrm{opt}}$ and thus fulfilling quality requirements.

\section{Method comparison}

Overall, 45 samples were included for the comparison between the POCT and the Gentian canine CRP immunoassay run on the ABX Pentra 400 analyzer. For the comparison between the POCT and AU 5800, 2/45 samples were excluded due to insufficient sample volume.

Intra-assay CVs obtained for duplicate CRP measurements for the three evaluated analyzers are shown in Table 6. As seen in the table, median CVs $<1 \%$ and $2 \%$ were obtained for the automated bench top analyzers ABX Pentra 400 and AU 5800 with a range of $0 \%-3.2 \%$ and $0.3-5.6 \%$ respectively.

For the POCT, median intra-assay $\mathrm{CVs}$ were $<6 \%$, however, there was a broad range especially in the low concentration range ( $0 \%$ to $38.9 \%$ ).

Results of the method comparison study are shown in Fig. 2. There was an excellent correlation between CRP measurements obtained with the three analyzers $\left(r_{s}\right.$ ranging between 0.98 and 0.99, Fig. 2 A1-3).

Passing-Bablok regression analysis revealed a correlation of $r_{s}=0.98$ between the data obtained with POCT and measurements of the ABX Pentra 400 with the regression eq. $\mathrm{Y}=-0.12+0.82 \times$. Regression analysis between POCT and AU 5800 revealed a Spearman's rank correlation coefficient of $\mathrm{r}_{\mathrm{s}}=0.99$ and the regression eq. $\mathrm{Y}=-0.52+0.91 \times$. In the additional correlation analysis between ABX Pentra 400 and AU 5800 using the same CRP assay, a Spearman's rank correlation coefficient of
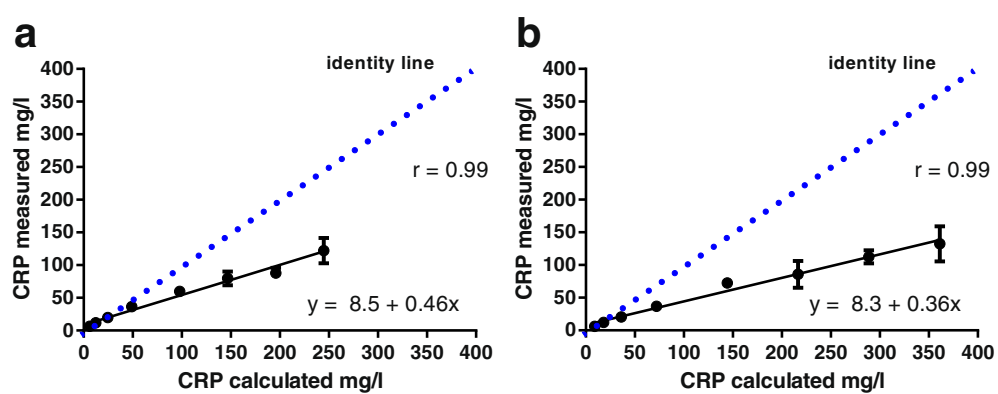

Fig. 1 Linearity of two diluted lithium heparin plasma samples with high CRP concentrations. a Linearity under dilution for measurement of a canine serum sample originally containing $244.8 \mathrm{mg} / \mathrm{l}$ CRP as assessed with the Pentra 400 bench top analyzer. $\mathbf{b}$ Linearity under dilution for measurement of a canine serum sample originally containing $361.3 \mathrm{mg} / \mathrm{I} C \mathrm{RP}$ as assessed with the Pentra 400 bench top analyzer. A serial dilution was performed in both cases to achieve 8 different CRP concentrations, i.e, 1.0, 0.8, 0.6, 0.4, 0.2, 0.1, 0.05, 0.025 parts of the original concentration 
Table 2 Linearity and recovery

\begin{tabular}{|c|c|c|c|c|c|c|}
\hline Dilution Factor & Expected concentration [mg/l] & $\begin{array}{l}\text { Mean measured } \\
\text { concentration [mg/l] }\end{array}$ & Recovery [\%] & Bias $_{\text {obs }}[\%]$ & $\%$ Bias $_{\text {obs }}<\mathrm{TE}_{\text {des }}(29.6 \%)$ & $\%$ Bias $_{\text {obs }}<\mathrm{TE}_{\min }(44.4 \%)$ \\
\hline \multicolumn{7}{|l|}{$\bar{A}$} \\
\hline 0.025 & 6.1 & 6.5 & 106.8 & 6.8 & Yes & Yes \\
\hline 0.05 & 12.2 & 11.9 & 97.0 & 3.1 & Yes & Yes \\
\hline 0.1 & 24.5 & 19.8 & 81.0 & 19.0 & Yes & Yes \\
\hline 0.2 & 49.0 & 36.5 & 74.6 & 25.5 & Yes & Yes \\
\hline 0.4 & 97.9 & 59.8 & 61.0 & 39.0 & No & Yes \\
\hline 0.6 & 146.9 & 79.8 & 54.3 & 45.7 & No & No \\
\hline 0.8 & 195.8 & 88.0 & 44.9 & 55.1 & No & No \\
\hline 1 & 244.8 & 122.3 & 50.0 & 50.1 & No & No \\
\hline \multicolumn{7}{|l|}{ B } \\
\hline 0.025 & 9.0 & 6.2 & 68.7 & 31.3 & No & No \\
\hline 0.05 & 18.1 & 12.3 & 68.3 & 31.7 & No & No \\
\hline 0.1 & 36.1 & 20.4 & 56.6 & 43.4 & No & No \\
\hline 0.2 & 72.2 & 36.7 & 50.8 & 49.2 & No & No \\
\hline 0.4 & 144.4 & 72.5 & 50.2 & 49.8 & No & No \\
\hline 0.6 & 216.6 & 85.8 & 39.6 & 60.4 & No & No \\
\hline 0.8 & 288.8 & 112.6 & 39.0 & 61.0 & No & No \\
\hline 1 & 361.3 & 132.4 & 36.7 & 63.4 & No & No \\
\hline
\end{tabular}

Linearity and recovery rates of CRP measurements performed with a canine serum sample containing A) $244.8 \mathrm{mg} / \mathrm{l}$ or B) $361.3 \mathrm{mg} / \mathrm{l}$ CRP respectively as determined on the ABX Pentra 400 analyzer

Quality parameters exceeding the quality criteria reported previously [32,36], are marked in bold letters

Abbreviations: $B_{i a s_{o b s}}$ observed bias, $T E$ total allowable error, $T E_{\text {des }}$ desirable $T E, T E_{\min }$ minimally acceptable $T E$

$\mathrm{r}_{\mathrm{s}}=0.99$ and the regression eq. $\mathrm{Y}=0.57+0.90 \times$ was obtained.

As demonstrated in Fig. 2 B1-2, Bland Altman analysis revealed a proportional Bias obs of $10.7 \%$ and $19.7 \%$ between CRP measurement obtained with the POCT and the two automated bench top analyzers AU 5800 and ABX Pentra 400, respectively. All three analyzers

Table 3 Intra- and inter-assay CVs obtained from replicate CRP measurements with the POCT

\begin{tabular}{|c|c|c|c|c|c|c|c|}
\hline \multirow{2}{*}{$\begin{array}{l}\text { Three CRP } \\
\text { concentration } \\
\text { ranges / analyzer }\end{array}$} & \multirow[t]{2}{*}{$\operatorname{Dog}^{a}$} & \multicolumn{3}{|c|}{$\begin{array}{l}\text { Intra-assay CV } \\
\text { ( } n=10 \text { replicates) }\end{array}$} & \multicolumn{3}{|c|}{$\begin{array}{l}\text { Inter-assay CV } \\
\text { ( } n=7 \text { replicates) }\end{array}$} \\
\hline & & $\begin{array}{l}\text { Mean } \\
(\mathrm{mg} / \mathrm{l})\end{array}$ & $\begin{array}{l}\mathrm{SD} \\
(\mathrm{mg} / \mathrm{l})\end{array}$ & $\begin{array}{l}\mathrm{CV} \\
(\%)\end{array}$ & $\begin{array}{l}\text { Mean } \\
(\mathrm{mg} / \mathrm{l})\end{array}$ & $\begin{array}{l}\mathrm{SD} \\
(\mathrm{mg} / \mathrm{l})\end{array}$ & $\begin{array}{l}\mathrm{CV} \\
(\%)\end{array}$ \\
\hline \multirow[t]{4}{*}{$\geq 10-<50 \mathrm{mg} / \mathrm{l}$} & 1 & 21.3 & 4.7 & 21.8 & 23.2 & 6.3 & 27.2 \\
\hline & 2 & 43.1 & 2.3 & 5.4 & 32.3 & 2.0 & 6.2 \\
\hline & 3 & 23.1 & 3.7 & 16.3 & 15.4 & 0.8 & 5.0 \\
\hline & 4 & 29.9 & 4.0 & 13.2 & 32.2 & 2.8 & 8.8 \\
\hline \multirow[t]{2}{*}{$\geq 50-<100 \mathrm{mg} / \mathrm{l}$} & 5 & 55.7 & 3.0 & 5.5 & 71.0 & 7.6 & 10.7 \\
\hline & 6 & 79.8 & 4.7 & 5.9 & 74.4 & 5.5 & 7.3 \\
\hline \multirow[t]{2}{*}{$\geq 100-<200 \mathrm{mg} / \mathrm{l}$} & 7 & 113.9 & 7.4 & 6.5 & 102.4 & 7.2 & 7.0 \\
\hline & 8 & 113.9 & 9.1 & 8.0 & 110.5 & 11.1 & 10.0 \\
\hline
\end{tabular}

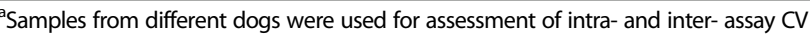
$\mathrm{CV}>\mathrm{CV}_{\text {des }}$ (i.e., $12.2 \%$ ) and $\mathrm{CV}>\mathrm{CV}_{\text {min }}$ (i.e., $18.2 \%$ ) is shown in bold letters Abbreviations: $S D$ standard deviation, $C V$ coefficient of variation, $C V_{\text {des }}$ desirable $\mathrm{CV}, \mathrm{CV}_{\text {min }}$ minimally acceptable $\mathrm{CV}$ revealed a growing absolute bias with increasing CRP concentration (Fig. 2 C1-3). Especially the POCT and ABX Pentra 400 analyzer disagreed considerably (Fig. 2 B1-2, C1-2) exceeding the $\%$ Bias $_{\min }$ of $14.3 \%$. Bias was lower between the POCT and the AU 5800 analyzer being $<\%$ Bias $_{\text {min. }}$. Interestingly, even between both bench top analyzers using the same CRP assay, a mean Bias ${ }_{\text {obs }}$ of 9.2\% was seen (Fig. 2 B3), which, however, was still < both $\%$ Bias $_{\text {des }}$ and $\% B_{i a s}$ min of $9.5 \%$ and $14.3 \%$, respectively. As shown in Fig. 3, there was a significant difference between mean CRP measurements obtained with all analyzers, whereby highest CRP measurements were

Table 4 Determination of the lower limit of quantification

\begin{tabular}{|c|c|c|c|c|c|}
\hline \multirow[t]{2}{*}{$\begin{array}{l}\text { Three low CRP } \\
\text { concentrations }\end{array}$} & \multirow[t]{2}{*}{ Dog } & \multicolumn{4}{|c|}{$\begin{array}{l}\text { Intra-assay CV } \\
\text { ( } n=20 \text { replicates) }\end{array}$} \\
\hline & & $\begin{array}{l}\text { Mean } \\
(\mathrm{mg} / \mathrm{L})\end{array}$ & $\begin{array}{l}\mathrm{SD} \\
(\mathrm{mg} / \mathrm{L})\end{array}$ & $\begin{array}{l}\mathrm{CV} \\
(\%)\end{array}$ & $\begin{array}{l}\% C V<C V_{\text {des }} \\
(12.2 \%)\end{array}$ \\
\hline$<1 \mathrm{mg} / \mathrm{l}$ & 1 & $<5^{*}$ & n.d. & n.d. & n.d. \\
\hline$\sim 10 \mathrm{mg} / \mathrm{L}$ & 2 & 11.5 & 0.7 & 6.2 & Yes \\
\hline$\sim 20 \mathrm{mg} / \mathrm{l}$ & 3 & 16.8 & 1.8 & 11.0 & Yes \\
\hline
\end{tabular}

Intra-assay $\mathrm{CV}$ s for the CRP analysis obtained from replicate measurements at low CRP values with the POCT

*values $<5 \mathrm{mg} / \mathrm{l}$ are generally reported as " $<5 \mathrm{mg} / \mathrm{l}$ ", therefore no further calculations were possible

Abbreviations: $S D$ standard deviation, $C V$ coefficient of variation, $C V_{\text {des }}$ desirable $\mathrm{CV}$, n.d. not done 
Table 5 Observed interference effects of bilirubin, hemoglobin, lipid on triplicate CRP measurement with the POCT

\begin{tabular}{|c|c|c|c|c|c|c|}
\hline Interferent & $\begin{array}{l}\text { Mean } \mathrm{CRP}_{\text {control }} \\
{[\mathrm{mg} / \mathrm{l}] \pm \mathrm{SD}}\end{array}$ & $\begin{array}{l}\text { Mean CRP } \\
\text { test } \\
{[\mathrm{mg} / \mathrm{l}] \pm \mathrm{SD}}\end{array}$ & $\begin{array}{l}\text { Mean bias } \\
{[\mathrm{mg} / \mathrm{l}]}\end{array}$ & $\%$ Bias $_{\text {obs }}$ & $\begin{array}{l}\text { \%Bias } \text { obs }<\mathrm{TE}_{\text {des }} \\
(29.6 \%)\end{array}$ & $\begin{array}{l}\text { \% } \text { Bias }_{\text {obs }}<\mathrm{TE}_{\mathrm{opt}} \\
(14.8 \%)\end{array}$ \\
\hline $\begin{array}{l}\text { Bilirubin } \\
800 \text { mg/l }\end{array}$ & $37.6 \pm 5.6$ & $39.8 \pm 0.4$ & 2.2 & 5.8 & Yes & Yes \\
\hline $\begin{array}{l}\text { Hemoglobin } \\
4 \mathrm{~g} / \mathrm{l}\end{array}$ & $29.5 \pm 1.7$ & $30.1 \pm 4.1$ & 0.6 & 2.0 & Yes & Yes \\
\hline Soy bean emulsion & $35.1 \pm 1.4$ & $39.1 \pm 0.8$ & 4.0 & 11.3 & Yes & Yes \\
\hline
\end{tabular}

$8 \mathrm{~g} / \mathrm{l}$

Test samples ( $\left.\mathrm{CRP}_{\text {test }}\right)$ spiked with the interfering substances were compared to control samples ( $\left.\mathrm{CRP}_{\text {control }}\right)$ spiked with equal volume of the diluent used in the test sample. \%Bias obs (observed bias) for the interfering substance was acceptable if \%Bias obs $<$ desired total allowable error ( $\mathrm{TE}_{\text {des }}$ ) and excellent if \%Bias obs $<$ optimal total allowable error ( $\left.\mathrm{TE}_{\mathrm{opt}}\right)$ [32]

obtained with the ABX Pentra 400 analyzer and lowest results with the POCT. Median (minimum to maximum) values obtained were $76.00 \mathrm{mg} / \mathrm{l}$ (17.05-201.4 mg/l), $59.35 \mathrm{mg} / \mathrm{l}(14.90-177.0 \mathrm{mg} / \mathrm{l})$ and $68.18 \mathrm{mg} / \mathrm{l}(16.38-177.4 \mathrm{mg} / \mathrm{l})$ for the ABX Pentra 400, the POCT and the AU 5800, respectively.

As shown in Table 7, quality requirements were fulfilled as $\mathrm{TE}_{\mathrm{obs}}$ remained $<\mathrm{TE}_{\mathrm{min}}$ of $44.4 \%$ for all comparisons. For the majority of comparisons, $\mathrm{TE}_{\mathrm{obs}}$ was also $<\mathrm{TE}_{\mathrm{des}}$ of $29.6 \%$. The only exception was the comparison between the POCT and ABX Pentra 400 for CRP concentrations $>100 \mathrm{mg} / \mathrm{l}$, where a $\mathrm{TE}_{\mathrm{obs}}$ of $31.9 \%$ was obtained.

\section{Establishment of reference intervals}

Overall, 60 clinically healthy dogs with a median age of 2 years (range 1-9 years) were included to evaluate a reference range for CRP as assessed with the POCT. Sex was equally distributed with 30 male (25 intact, 5 neutered) and 30 female (28 intact, 2 spayed) dogs. The breeds were represented as follows: 11 German Shepherd Dogs, 9 Golden Retrievers, 9 Labrador Retrievers, 7 mixed-breed dogs, 6 Bearded Collies, 3 Great Danes, 2 Australian Kelpies, 2 Dogues de Bordeaux, 2 Rough Collies, 2 Rhodesian Ridgebacks, 1 Bernese Mountain Dog, and 1 Border Collie, Boxer, Bullmastiff, Cane Corso Italiano, Hovawart, Magyar Viszla each.

Healthy dogs presented with CRP values $\leq 11.9 \mathrm{mg} / \mathrm{l}$.

Table 6 Results of method comparison: Intra-assay precision

\begin{tabular}{llll}
\hline $\begin{array}{l}\text { Intra-assay CV median } \\
\text { (range) at three CRP } \\
\text { concentration } \\
\text { ranges / analyzer }\end{array}$ & $\begin{array}{l}\text { Point } \\
\text { Reader }^{\mathrm{TM}} \mathrm{V}\end{array}$ & $\begin{array}{l}\text { ABX } \\
\text { Pentra 400 }\end{array}$ & AU 5800 \\
\hline$\geq 10-<50 \mathrm{mg} / \mathrm{l}$ & $3.53 \%$ & $0.62 \%$ & $0.76 \%$ \\
& $(0.0-38.91 \%)$ & $(0.0-3.23 \%)$ & $(0.26-3.0 \%)$ \\
$\geq 50-<100 \mathrm{mg} / \mathrm{l}$ & $3.50 \%$ & $0.43 \%$ & $1.68 \%$ \\
& $(0.16-7.39 \%)$ & $(0.08-2.21 \%)$ & $(0.49-5.60 \%)$ \\
$\geq 100-<200 \mathrm{mg} / \mathrm{l}$ & $5.62 \%$ & $0,30 \%$ & $1.50 \%$ \\
& $(0.40-16.60 \%)$ & $(0.0-0.60 \%)$ & $(0.52-2.27 \%)$
\end{tabular}

Intra-assay CVs for the CRP analysis obtained from duplicate measurements performed on two automated bench top analyzers (ABX Pentra, AU 5800) and the point-of-care analyzer

Abbreviations: CV coefficient of variation

\section{Discussion}

The POCT was capable to detect canine CRP with an excellent correlation with the automated immunoturbidimetric test run on large bench top analyzers in both, a university veterinary laboratory and a commercial veterinary laboratory, even though a proportional bias of the assay has to be considered. Generally, quality requirements were fulfilled as $\mathrm{TE}_{\mathrm{obs}}$ remained $<\mathrm{TE}_{\text {min }}$ of $44.4 \%$ and for the majority of comparisons $<\mathrm{TE}_{\mathrm{des}}$ of $29.6 \%$ [32]. This is in accordance with other POCTs for canine CRP [27]. Intra- and inter-assay CVs ranging from 0 to $24 \%$ have been reported for different other POCTs at low CRP concentrations which was generally consistent with the results obtained here [27].

For pathologically relevant CRP concentrations of > $50 \mathrm{mg} / \mathrm{l}$, the POCT fulfilled quality requirements, i.e intra- and inter-assay $\mathrm{CVs}<\mathrm{CV}_{\text {opt }}$ or at least $<\mathrm{CV}_{\text {des }}$. Other than expected and described previously for various assays [28, 29], highest CVs were not obtained for samples in the lowest CRP concentration range, but at low to medium CRP concentrations of 20-30 mg/l. Possible explanations may be "hardware errors" due to biochemical background reactions of the assay itself or an impairment of the optical detection. Variations between different lots or individual test stripes of the assay are another possible source of error. However, in case of lot-associated variations, outliers would be observed at several different CRP concentration ranges rather than at one single concentration range. Alternative explanations are user-dependent errors as dilution- and pipetting errors. User-dependent errors, however, were minimized as all measurements were performed by two trained persons. Although analytical imprecision in the concentration range between CRP concentrations of 20 and $30 \mathrm{mg} / \mathrm{l}$ is not desirable, it is considered of minor clinical relevance as it generally does not have an impact of the clinical decision, i.e. interpretation of the CRP results as mildly increased. However, the possibility of a CV of $20-30 \%$ has to be taken into account when interpreting follow-up examinations of the patient.

The current evaluation clearly showed that a bias between the methods has to be expected even when the 


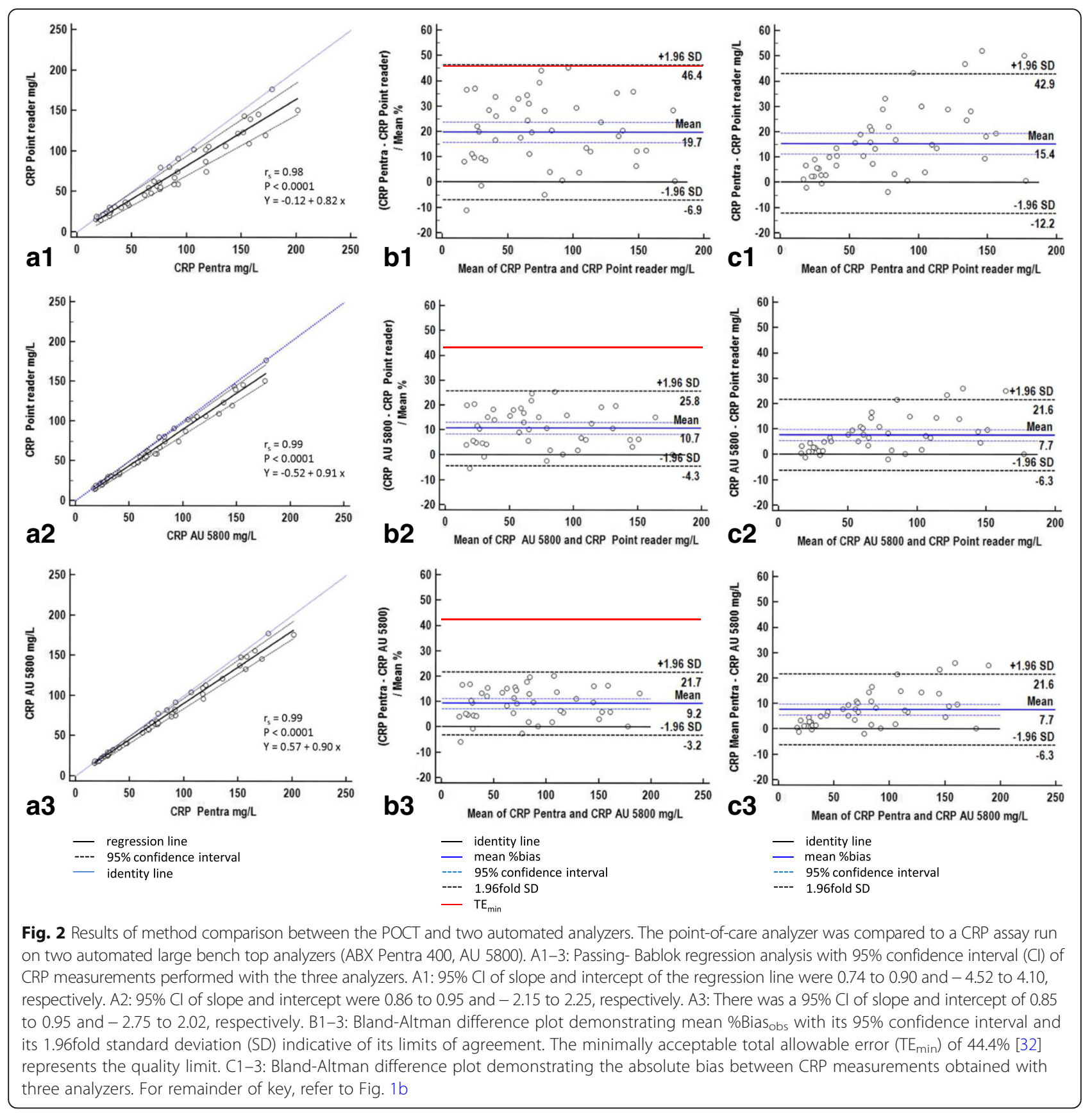

same test is used as it was the case for the ABX Pentra 400 and the AU 5800 bench top analyzer. The current results show that the bias is not only caused by the different ability of the antibody used in the test to bind canine CRP but also by the analyzer itself. The impact of the analyzer on assay results has already been discussed in the literature for the same CRP assay which is used as reference method in the current study [27, 29]. Moreover, an impact of different lots of the Gentian Canine CRP Immunoassay on the results cannot be entirely ruled out.
As demonstrated here, the bias and thus also the $\mathrm{TE}_{\mathrm{obs}}$ are highly dependent on the reference method (i.e., the combination of assay and analyzer) used for comparison. While \% $\mathrm{Bias}_{\mathrm{obs}}$ between the POCT and the bench top analyzer AU 5800 was at least fulfilling $\%$ Bias $_{\min }$ [32], \%Bias ${ }_{\text {obs }}$ was slightly higher than Bias $_{\text {min }}$ in the comparison between the POCT and the other bench top analyzer, ABX Penta 400. Other than expected, even the comparison between both bench top analyzers using the same assay revealed a mean \%Bia$\mathrm{s}_{\text {obs }}>$ than optimal bias $\%$ Bias $_{\text {opt }}$. The results obtained 


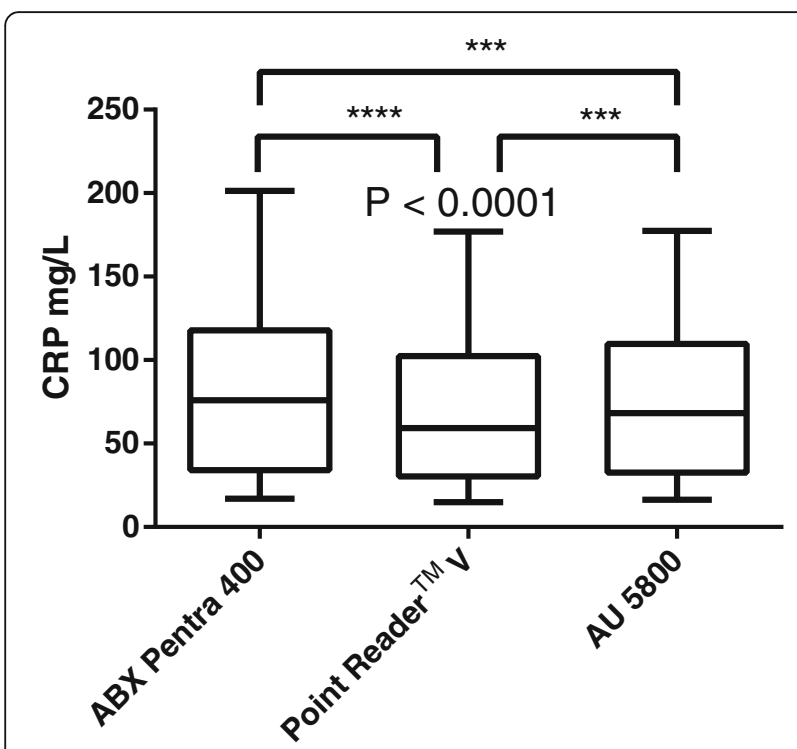

Fig. 3 Results of method comparison: Differences of medians and ranges between the analyzers. Box- and - whisker diagram demonstrating median and range of the CRP measurements obtained with the three analyzers. The horizontal line in the boxes is consistent with the median, the whiskers indicate the range and the box represents the 25th -75th percentile

here, demonstrate clearly the impact of the choice of the reference method on the results.

Unfortunately, a true gold standard is not available for the measurement of canine CRP, which is a major limitation of all method validation studies. Considering the \%Bias ${ }_{\text {obs }}$ between both large bench top analyzers evaluated here and using the same assay, a Bias ${ }_{\text {obs }}$ of $\sim 10 \%$ between the POCT and the AU 5800 can be considered as good while a Bias ${ }_{\text {obs }}$ of $~ 20 \%$ between the POCT and the ABX Pentra 400 may at least be considered as satisfying. Regarding the literature, a mean \%bias ranging between $\sim 10-30 \%$ is frequently reported in method validation studies for POCT designed for canine CRP analysis [27]. Due to the $\mathrm{Bias}_{\mathrm{obs}}$, it can be concluded that test- and analyzer -specific reference intervals and clinical decision limits have to be established. Follow-up examinations should be therefore performed with the same

Table 7 Results of method comparison: Total observed error

\begin{tabular}{llll}
\hline $\begin{array}{l}\mathrm{TE}_{\mathrm{obs}} \text { at three CRP } \\
\begin{array}{l}\text { concentration } \\
\text { ranges / analyzer }\end{array}\end{array}$ & $\begin{array}{l}\mathrm{ABX} \text { Pentra } \\
400 \mathrm{vs} P O C T\end{array}$ & $\mathrm{AU} 5800$ vs POCT & $\begin{array}{l}\mathrm{ABX} \text { Pentra } \\
400 \text { vs AU } 5800\end{array}$ \\
\hline$\geq 10-<50 \mathrm{mg} / \mathrm{l}$ & $27.3 \%$ & $17.3 \%$ & $10.7 \%$ \\
$\geq 50-<100 \mathrm{mg} / \mathrm{l}$ & $26.7 \%$ & $16.7 \%$ & $12.6 \%$ \\
$\geq 100-<200 \mathrm{mg} / \mathrm{l}$ & $\mathbf{3 1 . 9 \%}$ & $21.9 \%$ & $12.2 \%$ \\
\hline
\end{tabular}

Total observed error ( $\mathrm{TE}_{\mathrm{obs}}$ ) for the CRP analysis performed on two automated bench top analyzers (ABX Pentra 400, AU 5800) and the point-of-care analyzer $T E_{\text {obs }}>\mathrm{TE}_{\text {des }}$ (i.e., $29.6 \%$ ) but $<\mathrm{TE}_{\text {min }}$ (i.e., $44.4 \%$ ) is shown in bold letters Abbreviations: vs versus, $T E_{\text {des }}$ desirable total allowable error, $T E_{\min }$ minimally acceptable total error method and analyzer [27]. Bias between results obtained with different analyzers should be also kept in mind, when classifying the severity of CRP increase as mild, moderate or severe. Also, CRP clinical decision limits reported in literature may not be applicable for the POCT [9]. As the POCT correlates well with the reference method $(r>0.975)$ [31], the regression equation may be used to adapt values reported by the POCT to values of the Gentian Canine CRP Immunoassay [37], i.e. a CRP value of $100 \mathrm{mg} / \mathrm{l}$ on the ABX Pentra 400 is consistent with $80 \mathrm{mg} / \mathrm{l}$ on the POCT and $90 \mathrm{mg} / \mathrm{l}$ on the AU 5800 , while a value of $50 \mathrm{mg} / \mathrm{l}$ is consistent with $40 \mathrm{mg} / \mathrm{l}$ $(\mathrm{Y}=-0.12+0.82 \mathrm{x})$ and $45 \mathrm{mg} / \mathrm{l}(\mathrm{Y}=-0.52+0.91 \mathrm{x})$, respectively. Still, the option to use the equation of the regression analysis has to be considered carefully and is not recommended for general use (i.e, incorporation into analyzers' software) as measuring errors potentiate via mathematical adaption and the true origin of results becomes non-transparent.

The linearity experiment demonstrated linearity of the POCT up to a CRP concentration of $130 \mathrm{mg} / \mathrm{l}$ as well as an excellent correlation between measured and calculated values. However, the slope of the regression line was markedly below 1 also reflecting a marked proportional bias.

The evaluation of the lower limit of quantification was impaired by two facts: First, the POCT has an internal technically predetermined "limit of quantified report". Low CRP concentrations $<5 \mathrm{mg} / \mathrm{l}$ are generally reported as " $<5 \mathrm{mg} / \mathrm{l}$ " by the analyzer. Second, results of repeated measurements of the analyzer at low CRP concentrations $<30 \mathrm{mg} / \mathrm{l}$, CVs are good to excellent in most cases, but single "outliers" occurred resulting in a high $\mathrm{CV}$ (Tables 3 and 4). Therefore, it is questionable if the evaluation of two samples with low CRP concentration levels above the reported limit of the analyzer is enough to determine a lower limit of quantification. A higher number of analyses of samples with CRP values $>5 \mathrm{mg} / \mathrm{l}$ but $<30 \mathrm{mg} / \mathrm{l}$ would be needed to increase the validity of the set limit. Regarding our own observations (Table 4), the limit of $5 \mathrm{mg} / \mathrm{l}$ fixed internally in the analyzer appears to be a good limit for reported values.

No interferences in clinically relevant ranges of up to $800 \mathrm{mg} / \mathrm{l}$ bilirubin, $4 \mathrm{~g} / \mathrm{l}$ hemoglobin and $8 \mathrm{~g} / \mathrm{l}$ soy bean oil (Intralipid) could be detected. As metabolic disorders associated with icteric, hemolytic or lipemic samples occur frequently in patients with inflammatory diseases [20] or emergency patients, the lack of impairment by these circumstances is considered an advantage. In contrast, interferences have been reported previously for other CRP assays, although they had been considered without clinical relevance [38].

In our study, statistical computation of an exact reference interval for healthy dogs was not possible as in the 
majority of dogs CRP values $<5 \mathrm{mg} / \mathrm{l}$ were observed. Still, this is not a disadvantage as very low CRP values are not of clinical relevance in canine medicine. The data demonstrate healthy dogs to show CRP values < $12 \mathrm{mg} / \mathrm{l}$. This is comparable with most reported reference intervals for canine CRP established for various immunoassays in literature [16, 18-20,39] or our own unpublished data for the Gentian Canine CRP Immunoassay on the ABX Pentra 400 with a reference interval $\leq$ $10.8 \mathrm{mg} / \mathrm{l} \mathrm{CRP}$.

Nevertheless, another recent study [40] also reported a wide range of normal CRP results $(0.07-24.7 \mathrm{mg} / \mathrm{l}) \mathrm{ob}-$ tained in 76 healthy dogs using a human-based assay (High linearity CRP, Randox, Crumlin, United Kingdom). In the previous study, the clinical decision limit to differentiate between healthy dogs or dogs without systemic inflammation and dogs with several types of diseases associated with systemic inflammation was set at a CRP concentration of $16.8 \mathrm{mg} / \mathrm{l}$ based on receiver operating characteristic analysis. In contrast, in another study evaluating a semiquantitative near-patient CRP assay, a higher CRP concentration of $35 \mathrm{mg} / \mathrm{l}$ is used as a cut-off value to discriminate "positive" and "negative" CRP samples [24]. However, given the bias even between analyzers using the same assay, potential bias as well as the $\mathrm{CV}$ at this concentration level have to be considered. In case of marked bias, a laboratory-specific cut-off value has to be defined. Moreover, especially if a relatively high $\mathrm{CV}$ is present as observed for the POCT at this concentration range, a grey zone rather than a definite cut-off value should be used which can be calculated based on the analytical $\mathrm{CV}$ and biological variation, i.e. within dog variation as described previously [41].

Limitations of the study included the fact that quality specifications for $\mathrm{CV}$, bias and $\mathrm{TE}$ based on biological variation as published in the total allowable error guidelines of the ASVCP [42] were applied here, however, they are judged as too stringent for method validation studies [42] and are even stricter than quality goals in human medicine [43]. As no adequate alternative is available for veterinary medicine, they have been used also in previous studies evaluating canine CRP assays [29].

Moreover, a possible prozone effect was not investigated in our study, however, there is no evidence of a prozone effect for a CRP range $\leq 360 \mathrm{mg} / \mathrm{l}$ (equaling $130 \mathrm{mg} / \mathrm{l}$ as assessed with the POCT) which covers a large part but not the total range of possible CRP results observed in diseased dogs $[40,44]$.

\section{Conclusion}

Overall, the species-specific Point Reader ${ }^{\mathrm{rm}} \mathrm{V}$ is an easyto-use POCT suitable to detect canine CRP in lithium heparin plasma samples precisely in concentrations being relevant for clinical decision making. The POCT correlates well with an already established immunoturbidimetric species-specific CRP assay run on large bench top analyzers, however, the bias with other methods and analyzers has to be considered. Thus, CRP results assessed by different assays and/or different analyzers are not directly comparable in follow-up examinations.

\section{Abbreviations \\ APP: acute phase protein(s); Bias des: Desired bias; Bias min: Minimally acceptable bias; Biasobs: Observed bias; Bias opt: Optimal bias; CRP: C-reactive protein; $\mathrm{CV}$ : Coefficient of variation; $\mathrm{CV}_{\text {des: }}$ : Desired coefficient of variation; $\mathrm{CV}_{\text {opt: }}$ : Optimal coefficient of variation; ELISA: Enzyme-linked immunosorbent assay; LoQ: Limit of quantification; POCT: Point-of-care test; SD: Standard deviation; TE: Total error; $\mathrm{TE}_{\text {des: }}$ : Desired total allowable error; $\mathrm{TE}_{\min }$ : Minimally acceptable total allowable error; $\mathrm{TE}_{\mathrm{obs}}$ : Observed total allowable error; $\mathrm{TE}_{\mathrm{opt}}$ : Optimal total allowable error}

Acknowledgements

Not applicable.

\section{Funding}

The Point Strip ${ }^{T M}$ Canine CRP Assay and the Point Reader ${ }^{\top M} V$ were provided by USHIO Europe B.V., BC Oude Meer, The Netherlands. The study plan, conduction of analyses, interpretation of data as well as the decision to publish the results were not influenced by the funders. Writing of the manuscript was performed independent of the funders without any financial support.

\section{Availability of data and materials}

The datasets analyzed during the current study are available from the corresponding author on reasonable request.

\section{Authors' contributions}

SH conceived the study design, participated in data collection and statistical analysis, data interpretation and drafted the manuscript. MK participated in study design and conducted analyses on the Point Reader ${ }^{\mathrm{TM}} \mathrm{V}$. SZ collected numerous blood samples and was involved in study design as well as conducted analyses on the ABX Pentra 400. JL planned and conducted analyses on the AU 5800 and was involved in discussing the data. AM participated in project planning and coordination and supervised the study. NB supervised project planning, performed most of the statistical analyses, data interpretation and was involved in discussing the results and writing of the manuscript. All authors read and approved the final manuscript.

\section{Ethics approval and consent to participate}

The study was conducted in accordance with the German Animal Welfare Act (Article 8). The competent authority was informed. According to the information of our ethics committee (Regierungspräsidium Giessen, Dezernat 54 - Veterinärwesen/Nerbraucherschutz, Wetzlar, Germany, ethics committee number: Gl 17/18), a particular approval for the study was not needed, because the study itself was not the indication of blood sampling and did not require taking an additional amount of blood.

For the diseased dogs, the measurement of CRP was part of the routine clinical chemical profile, whereby $1-21.2 \mathrm{~cm}^{3}$ heparin tubes for measurement of CRP on the ABX Pentra 400 and the remainder clinical chemical measurands was required. Evaluation on the Point Reader ${ }^{T M} V$ was conducted from superfluous heparinized plasma as only $10 \mu$ were necessary. The healthy dogs included in this study were presented in the Department of Veterinary Clinical Sciences in Giessen, Germany, either for health assessments or as blood donors. This part of the study served also for establishment of reference intervals for another evaluation and was ethically approved by the ethics committee (Regierungspräsidium Giessen, Dezernat 54 - Veterinärwesen/Nerbraucherschutz, Wetzlar, Germany, ethics committee number: Gl 17/18, reference number V54-19c2015hO2GI18/17 kTV/2017).

Consent for publication

Not applicable.

Competing interests

The authors declare that they have no competing interests. 


\section{Publisher's Note}

Springer Nature remains neutral with regard to jurisdictional claims in published maps and institutional affiliations.

\section{Author details}

'Department of Veterinary Clinical Sciences, Clinical Pathology and Clinical Pathophysiology, Justus-Liebig-University Giessen, Frankfurter Str. 126, 35392 Giessen, Germany. ${ }^{2}$ SYNLAB Vet GmbH, Augsburg, Germany.

Received: 6 December 2017 Accepted: 8 March 2018 Published online: 20 March 2018

\section{References}

1. Higgins MA, Berridge BR, Mills BJ, Schultze AE, Gao H, Searfoss GH, et al. Gene expression analysis of the acute phase response using a canine microarray. Toxicol Sci. 2003;74:470-84. https://doi.org/10.1093/toxsci/kfg142.

2. Cerón JJ, Eckersall PD, Martínez-Subiela S. Acute phase proteins in dogs and cats: current knowledge and future perspectives. Vet Clin Pathol. 2005;34: 85-99. https://doi.org/10.1111/j.1939-165X.2005.tb00019.x.

3. Eckersall PD, Bell R. Acute phase proteins: biomarkers of infection and inflammation in veterinary medicine. Vet J. 2010;185:23-7. https://doi.org/10. 1016/j.tvj.2010.04.009.

4. Torrente C, Manzanilla EG, Bosch L, Fresno L, Rivera Del Alamo M, Andaluz A, et al. Plasma iron, C-reactive protein, albumin, and plasma fibrinogen concentrations in dogs with systemic inflammatory response syndrome. J Vet Emerg Crit Care (San Antonio). 2015;25:611-9. https:/doi.org/10.1111/vec.12340.

5. Burton SA, Honor DJ, Mackenzie AL, Eckersall PD, Markham RJ, Horney BS. C-reactive protein concentration in dogs with inflammatory leukograms. Am J Vet Res. 1994; 55(5):613-8

6. Martínez-Subiela S, Tecles F, Eckersall PD, Cerón JJ. Serum concentrations of acute phase proteins in dogs with leishmaniasis. Vet Rec. 2002;150:241-4.

7. Ulutas B, Bayramli G, Ulutas PA, Karagenc T. Serum concentration of some acute phase proteins in naturally occurring canine babesiosis: a preliminary study. Vet Clin Pathol. 2005;34:144-7.

8. K-w S, Lee J-b, Ahn J-O, Lee H-w, C-y H, H-y Y, Lee C-w. C-reactive protein as an indicator of inflammatory responses to experimentally induced cystitis in dogs. J Vet Sci. 2012;13:179-85. https://doi.org/10.4142/jvs.2012.13.2.179.

9. Viitanen SJ, Laurila HP, Lilja-Maula LI, Melamies MA, Rantala M, Rajamäki MM. Serum C-reactive protein as a diagnostic biomarker in dogs with bacterial respiratory diseases. J Vet Intern Med. 2014;28:84-91. https://doi.org/10. 1111/jvim.12262

10. Tecles F, Spiranelli E, Bonfanti U, Cerón JJ, Paltrinieri S. Preliminary studies of serum acute-phase protein concentrations in hematologic and neoplastic diseases of the dog. J Vet Intern Med. 2005;19:865-70.

11. Kjelgaard-Hansen M, Jensen AL, Houser GA, Jessen LR, Kristensen AT. Use of serum C-reactive protein as an early marker of inflammatory activity in canine type II immune-mediated polyarthritis: case report. Acta Vet Scand. 2006;48:9. https://doi.org/10.1186/1751-0147-48-9.

12. Bathen-Noethen A, Carlson R, Menzel D, Mischke R, Tipold A. Concentrations of acute-phase proteins in dogs with steroid responsive meningitis-arteritis. J Vet Intern Med. 2008;22:1149-56. https://doi.org/10. 1111/j.1939-1676.2008.0164.x

13. Nielsen L, Toft N, Eckersall PD, Mellor DJ, Morris JS. Serum C-reactive protein concentration as an indicator of remission status in dogs with multicentric Iymphoma. J Vet Intern Med. 2007;21:1231-6. https://doi.org/10.1111/j.19391676.2007.tb01943.x.

14. Nakamura M, Takahashi M, Ohno K, Koshino A, Nakashima K, Setoguchi A, et al. C-reactive protein concentration in dogs with various diseases. J Vet Med Sci. 2008;70:127-31. https://doi.org/10.1292/jvms.70.127.

15. Dabrowski R, Wawron W, Kostro K. Changes in CRP, SAA and haptoglobin produced in response to ovariohysterectomy in healthy bitches and those with pyometra. Theriogenology. 2007;67:321-7. https://doi.org/10.1016/j. theriogenology.2006.07.019.

16. Kjelgaard-Hansen M, Kristensen AT, Jensen AL. Evaluation of a commercially available enzyme-linked immunosorbent assay (ELISA) for the determination of C-reactive protein in canine serum. J Vet Med Series A. 2003;50:164-8. https://doi.org/10.1046/j.1439-0442.2003.00509.x.

17. Fransson BA, Bergström A, Wardrop KJ, Hagman R. Assessment of three automated assays for C-reactive protein determination in dogs. Am J Vet Res. 2007;68:1281-6. https://doi.org/10.2460/ajvr.68.12.1281.
18. Kjelgaard-Hansen M, Jensen AL, Kristensen AT. Evaluation of a commercially available human C-reactive protein (CRP) turbidometric immunoassay for determination of canine serum CRP concentration. Vet Clin Pathol. 2003;32: 81-7. https://doi.org/10.1111/j.1939-165X.2003.tb00319.x.

19. Klenner S, Bauer N, Moritz A. Evaluation of three automated human immunoturbidimetric assays for the detection of C-reactive protein in dogs. $J$ Vet Diagn Invest (Journal of Veterinary Diagnostic Investigation). 2010;22: 544-52. https://doi.org/10.1177/104063871002200408.

20. Hillström A, Hagman R, Tvedten H, Kjelgaard-Hansen M. Validation of a commercially available automated canine-specific immunoturbidimetric method for measuring canine C-reactive protein. Vet Clin Pathol. 2014;43: 235-43. https://doi.org/10.1111/vcp.12150.

21. Monteny M, ten Brinke MH, van Brakel J, de Rijke YB, Berger MY. Point-ofcare $\mathrm{C}$-reactive protein testing in febrile children in general practice. Clin Chem Lab Med. 2006;44:1428-32. https://doi.org/10.1515/CCLM.2006.270.

22. Oh SW, Moon JD, Park SY, Jang HJ, Kim JH, Nahm KB, Choi EY. Evaluation of fluorescence hs-CRP immunoassay for point-of-care testing. Clin Chim Acta. 2005;356:172-7. https://doi.org/10.1016/j.cccn.2005.01.026.

23. McGrotty YL, Ramsey IK, Reid SWJ, Eckersall PD. Evaluation of a rapid assay for canine C-reactive protein. Vet Rec London. 2004;154:175-6.

24. Kjelgaard-Hansen M, Stadler M, Jensen AL. Canine serum C-reactive protein detected by means of a near-patient test for human C-reactive protein. J Small Anim Pract. 2008;49:282-6. https://doi.org/10.1111/j.1748-5827.2008.00541.x.

25. Plickert HD, Einspanier R, Arndt G, Brunnberg L, Kohn B. Evaluation of a point-of-care test for canine C-reactive protein. Vet Clin Pathol. 2011;40:3848. https://doi.org/10.1111/j.1939-165X.2011.00339.x.

26. Smuts CM, Mills JN, Gaál T. Comparison of a qualitative canine C-reactive protein test to a quantitative test and traditional markers of inflammation short communication. Acta Vet Hung. 2015;63:317-22. https://doi.org/10. 1556/004.2015.029.

27. Jasensky A-K, Klenner S, Einspanier R, Kohn B. Evaluation of three different point-of-care tests for quantitative measurement of canine C-reactive protein. Vet Clin Pathol. 2015;44:205-14. https://doi.org/10.1111/vcp.12264.

28. Muñoz-Prieto A, Tvarijonaviciute A, Escribano D, Martinez-Subiela S, Ceron $J$ J. Use of heterologous immunoassays for quantification of serum proteins: the case of canine C-reactive protein. PLoS One. 2017;12:1-14/14. https:// doi.org/10.1371/journal.pone.0172188.

29. Hindenberg S, Klenner-Gastreich S, Kneier N, Zielinsky S, Gommeren K Bauer N, Moritz A. Evaluation of a species-specific C-reactive protein assay for the dog on the ABX Pentra 400 clinical chemistry analyzer. BMC Vet Res. 2017;13:146. https://doi.org/10.1186/s12917-017-1065-9.

30. Armbruster DA, Pry T. Limit of blank, limit of detection and limit of quantitation. Clin Biochem Rev. 2008:49-52.

31. Jensen AL, Kjelgaard-Hansen M. Method comparison in the clinical laboratory. Vet Clin Pathol. 2006;35:276-86. https://doi.org/10.1111/j.1939165X.2006.tb00131.X.

32. Harr KE, Flatland B, Nabity M, Freeman KP. ASVCP guidelines: allowable total error guidelines for biochemistry. Vet Clin Pathol. 2013;42:424-36. https:// doi.org/10.1111/vcp.12101.

33. Jensen AL, Kjelgaard-Hansen M. Diagnostic test validation. In: Weiss DJ, Wardrop KJ, editors. Schalm's veterinary hematology. 6th ed. Ames: WileyBlackwell; 2010. p. 1027-33.

34. Andreasson U, Perret-Liaudet A, van Doorn $\vee$ W, Linda JC, Blennow K, Chiasserini D, Engelborghs $\mathrm{S}$, et al. A practical guide to immunoassay method validation. Front Neurol. 2015; https://doi.org/10.3389/fneur.2015.00179.

35. American Society for Veterinary Clinical Pathology (ASVCP). Principles of quality assurance and standards for veterinary clinical pathology. 2009. [http://www. asvcp.org/pubs/pdf/ASVCPQualityControlGuidelines.pdf]. Accessed 9 Mar 2018.

36. Papasouliotis K, Cue S, Crawford E, Pinches M, Dumont M, Burley K. Comparison of white blood cell differential percentages determined by the in-house LaserCyte hematology analyzer and a manual method. Vet Clin Pathol. 2006;35:295-302. https://doi.org/10.1111/j.1939-165X.2006.tb00134.x.

37. James O. Westgard P. Basic method validation, 3rd edition, FAQs. 2009. https://www.westgard.com/bmv3edfags.htm. Accessed 9 Mar 2018.

38. Martinez-Subiela S, Ceron JJ. Effects of hemolysis, lipemia, hyperbilirubinemia, and anticoagulants in canine c-reactive protein, serum amyloid a, and ceruloplasmin assays. Can Vet J. 2005:625-9.

39. Parra MD, Tuomola M, Cabezas-Herrera J, Cerón JJ. Analytical and clinical validation of a time-resolved immunofluorometric assay (TR-IFMA) for canine C-reactive protein in serum. Vet Res Commun. 2006;30:113-26. https://doi.org/10.1007/s11259-006-3201-z. 
40. Christensen MB, Langhorn R, Goddard A, Andreasen EB, Moldal E, Tvarijonaviciute $A$, et al. Comparison of serum amyloid $A$ and $C$-reactive protein as diagnostic markers of systemic inflammation in dogs. Can Vet J. 2014;55:161-8.

41. Freeman KP. Grey zones - better definition by use of biologic variation data. 19th ESVCP-ECVCP annual congress 2017; 2017. p. 28-9.

42. Harr KE, Flatland B, Nabity MB, Freeman KP. ASVCP guidelines allowable Total error: biochemistry. Approved version 1.0. 2013.

43. Ricos C, Alvarez V, Cava F, Garcia-Lario J, Hernandez A, Jimenez C, et al. Desirable biological variation database specifications - Westgard. 2014. [https://www.westgard.com/biodatabase1.htm]. Accessed 9 Mar 2018.

44. Gebhardt C, Hirschberger J, Rau S, Arndt G, Krainer K, Schweigert FJ, et al. Use of $\mathrm{C}$-reactive protein to predict outcome in dogs with systemic inflammatory response syndrome or sepsis. J Vet Emerg Crit Care (San Antonio). 2009;19:450-8. https://doi.org/10.1111/j.1476-4431.2009.00462.x.

Submit your next manuscript to BioMed Central and we will help you at every step:

- We accept pre-submission inquiries

- Our selector tool helps you to find the most relevant journal

- We provide round the clock customer support

- Convenient online submission

- Thorough peer review

- Inclusion in PubMed and all major indexing services

- Maximum visibility for your research

Submit your manuscript at www.biomedcentral.com/submit
Biomed Central 